\title{
Will Small be Beautiful? Making Policies for our Nanotech Future
}

\author{
W. Patrick McCray
}

With the passage of the National Nanotechnology Initiative (NNI) in 2000, US investment in nanotechnology research and development soared quickly to almost US\$1 billion annually. The NNI emerged at a salient point in US history as lawmakers worked to reshape national science policies in response to growing international economic competition and the increasing commercialization of academic science. This paper examines how advocates of nanotechnology successfully marketed their initiative. It pays especial attention to their optimistic depiction of societies and economies improved by nanotechnology, and considers why utopian techno-visions continue to flourish despite their tendency to ultimately disappoint.

Keywords: Nanotechnology; Science Policy; Technological Utopias

It was as if nanotechnology had gone through a phase transition; what had once been perceived as blue sky research ... was now being seen as the key technology of the 21 st century. ${ }^{1}$

On 24 October 2003, California politicians, academics, and civic leaders attended the groundbreaking ceremony for the California NanoSystems Institute in Santa Barbara. This US\$55 million high-tech building, with its ultra-filtered clean rooms and modular laboratories, represented only a fraction of the burgeoning national investment in nanotechnology. ${ }^{2}$ Since 2000, when President William J. Clinton announced a new national initiative to foster the tools of the 'next industrial revolution,' dozens of universities and corporations have initiated programs where scientists and engineers research phenomena and technologies at the nanoscale. ${ }^{3}$

Following proclamations by Clinton and other leaders, government and commercial investment into nanotechnology soared. In 2004, federal agencies in the USA dispensed

\footnotetext{
W. Patrick McCray is an assistant professor in the History Department at the University of California at Santa Barbara, USA. Email: pmccray@history.ucsb.edu. He is the author, most recently, of Giant Telescopes: Astronomical Ambition and the Promise of Technology (Cambridge, MA: Harvard University Press, 2004). He is currently engaged in a pilot research project that examines the recent history of nanotechnology with especial emphasis on science policy, community formation, public perceptions, and the collection of oral histories.
} 
almost a billion dollars a year to eager researchers (Figure 1 shows the federal funding profile for nanotechnology research). ${ }^{4}$ Meanwhile, forecasts, not from intemperate prognosticators but sober-minded science managers, predicted that the international market for nano-goods would be US $\$ 1$ trillion by 2015 . The production of these goods, supporters said, would require a new high-tech (and highly paid) workforce of some two million people, potentially leading to major restructuring of the global workforce. ${ }^{5}$

To its advocates, nanotechnology is a 'transcendent realm,' a regime where research in the physical and biotechnological sciences may converge with information technologies and the cognitive sciences. ${ }^{6}$ While definitions of what nanotechnology is varyindeed, one of its rhetorical strengths would seem to be its interpretive flexibility-its basic feature is 'smallness." ${ }^{7}$ According to official government definitions in the USA, nanotechnology involves three key components; research and technology development at the length scale of 1-100 nm; creating structures and devices that have novel properties and applications because of their small to intermediate size; and the ability 'to control or manipulate on the atomic scale. ${ }^{8}$

Nanotechnology, in other words, is engineering done at the molecular scale and represents the ability to deliberately shape new structures, atom by atom. Compared with the behavior of individual atoms or molecules (the latter being about $1 \mathrm{~nm}$ in size) or the properties of bulk materials, the behavior of structures in the size range of a few to a $100 \mathrm{~nm}$ is quite different. In this regime, the effects of surface area, interfaces, and

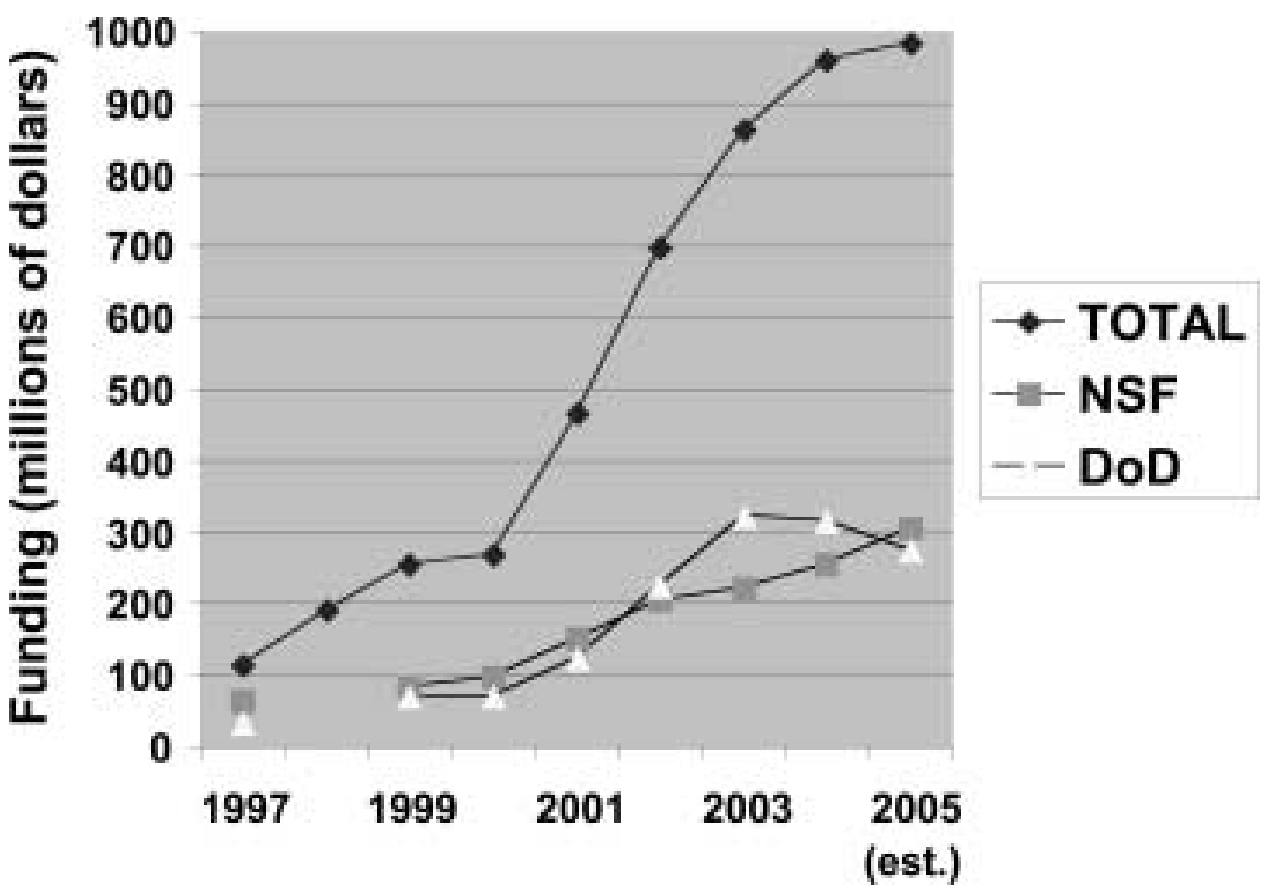

Figure 1 Funding Profile for Nanotechnology Research in the USA, 1997-2005. Total funding is shown along with monies allocated specifically to the National Science Foundation and the Department of Defense. 2005 figures are projected; breakdowns by agency not available for 1998. Source: Roco, 'The US National.' 
quantum behavior can create new behaviors and properties. Because the nanoscale is where the basic structure of materials are established and their properties defined, advocates of nanotechnology predict the creation of revolutionary nanostructures from the 'bottom up.' If realized, the ability of nanotechnologists to shape materials and structures with atomic precision would be the culmination of humans' expanding ability to manipulate their material world.

Humans, with varying degrees of intent, have been nanotechnologists for millennia. Ancient artisans have consciously manipulated metal, glass, and ceramic materials to create certain properties. Consider the Lycurgus Cup, a 4th-century glass vessel in the collection of the British Museum. The object's unusual optical properties are caused by a haphazard dispersion of nanometer-sized particles of a gold-silver alloy in a glass matrix. ${ }^{9}$ Nanotechnology's potential, its advocates claim, rests in its promise for precise control. In their view, it offers the ability to organize atoms and molecules into usable novel materials, structures, or systems with physical, chemical, and biological properties that are either known or predictable via sophisticated computer modeling.

The marshalling of Congressional support for the National Nanotechnology Initiative (NNI) occurred against the background of post-Cold War (and, later, postSeptember 11) science and technology policies. Proponents of nanotechnology offered seductive visions of a tomorrow that appealed to citizens, scientists, and policy makers, visions that this article examines. As one Nobel laureate said in a government brochure designed to make nanotechnology visible to the public, 'Nanotechnology has given us the tools ... to play with the ultimate toy box of nature ... . The possibilities to create new things appear endless.' ${ }^{10}$ In testimony to Congress and in books written for the public as well as science and policy communities, technological visionaries and science administrators alike predicted that nanotechnology could 'change the nature of almost every human-made object in the next century' and, in doing so, not only alter our 'comprehension of nature and life ... [but] even influence societal and international relations.' ${ }^{11}$ These predictions, in turn, helped spur lawmakers to allocate billions of dollars for research and commercial development. Despite arguments from skeptics attempting to re-direct policy and commercial research and development efforts, government leaders eventually adopted and ratified these utopian predictions in national science policy when they approved the National Nanotechnology Initiative in 2000.

The sheer dollar amount, the rapidity of the funding increases, and the accompanying flood of books, websites, and pop culture references to what one author called the 'nanocosm' are sufficient to command attention from a wide array of disciplines in the academy. ${ }^{12}$ While scholars have made initial efforts to analyze the economic, social, ethical, and legal challenges posed by the predicted 'next wave' of technological innovation, historians have paid comparatively little attention to nanotechnology. ${ }^{13}$ While this lacuna is understandable as nanotechnology's potential benefits still reside largely in research laboratories (the major commercial products exploiting nanoscale research thus far are stain resistant pants and improved cosmetics), the relative dearth of historiography concerning nanotechnology with which one can engage makes the historian's task more difficult. It is too early to assess the economic or societal effects of 
nanotechnology; it is not premature, however, to examine the roots of and rationale for the United States' massive investment in the nanocosm. This article is therefore to be read as an exploratory reconnaissance of the funding and policy terrain of nanotechnology in the last decade and is written with the understanding that future documentation will add much more depth and detail to the story presented here.

What is required to create a successful new science initiative? Previous studies of policy-making for science have identified several variables for victory. These include the role of entrepreneurs who lobby for policies that support their goals as well as perceived national needs. Coordinated activity among agencies, interest groups, and researchers as well as budgetary and institutional contexts are other factors. ${ }^{14}$ Howard McCurdy, in his discussion of how Americans imagined space exploration, rightly notes that public policy also has an important subjective dimension whose roots are located in imagination and visions of the future. ${ }^{15}$ Why was the NNI successful in obtaining so much federal support and what was its 'subjective dimension'?

This article addresses the area where, in the late 1990s, utopian imaginings and policy rationales met fiscal realities. National science policy is frequently analyzed through, if not indeed seen as commensurate with, the politics and annual changes of science budgets. ${ }^{16}$ This article goes beyond the conflation of policies with budgets to explore how and why such monies were allocated. In describing how advocates for the NNI gradually orchestrated its funding, this paper offers a historical perspective on the promotion of a major national initiative to support nanotechnology in the USA. In looking at the rationales offered by lawmakers and science managers, I pay special attention to the depiction of future nano-utopias in support of policy goals.

Historians will recognize the marshalling of techno-utopian visions as a theme common to the history of many technologies. From household appliances to nuclear power and the Internet, the introduction of new technologies has often been accompanied, if not presaged, by wildly optimistic claims and unbridled enthusiasm. ${ }^{17}$ More often than not, enthusiasts and supporters of new and 'revolutionary' technologies have seen their predictions tempered by fiscal, social, or regulatory realities. The belief that the next industrial revolution will come from nanotechnology existed in conjunction with other more prosaic rationales, some relics from the Cold War, for funding the NNI. Besides considering how advocates promoted the NNI and how its funding reflects broader changes in national science and technology policy, it is important to ask why utopian techno-visions continue to flourish given their predilection to ultimately disappoint.

\section{Before the Flood}

Historians of science and technology have long recognized the existence of 'creation stories,' myth-like narratives for research communities that trace the development of a particular idea or invention back to a singularity-lone inventor or small teams who create a revolutionary breakthrough. For geneticists, there is Watson, Crick, and the double helix; for electrical engineers, Shockley, Brattain, and Bardeen's invention of the transistor looms large. 
Nanotechnologists' creation story can be traced to a precise point in space and time-the evening of 29 December 1959 when Caltech physicist Richard P. Feynman gave an after-dinner speech in Pasadena to members of the American Physical Society. Feynman, one of the most original physicists of the 20th century, gave his address, whimsically entitled 'There's Plenty of Room at the Bottom,' at a time when the mass production of microelectronics was just beginning and computers still occupied entire rooms. $^{18}$

Feynman described the potential benefits of 'manipulating and controlling things on a small scale', which he believed could be accomplished while still obeying the basic laws of physics. Scientists, he predicted, would build microscopic machines that could manipulate matter at a very small scale while engineering done at the 'bottom' would provide plenty of attractive research opportunities. Human control of matter at the atomic scale was, according to the Caltech physicist, a 'development which I think cannot be avoided' and he backed up his assertion by offering a thousand dollars 'to the first guy who can take the information on the page of a book and put it on an area 1/ 25,000 smaller in linear scale in such manner that it can be read by an electron microscope. ${ }^{19}$ In his talk, Feynman drew upon utopian visions proffered by contemporary fiction writers, which suggested, ironically, how the scientific and visionary aspects of nanotechnology were interconnected from its very beginning. ${ }^{20}$

Feynman never did any research that could be construed as nanoscience. ${ }^{21}$ Indeed the word 'nanotechnology' did not appear until 1974 and then in an obscure proceedings of a Japanese industrial conference. ${ }^{22}$ Nevertheless, Feynman's address became a crucial touchstone for future advocates of nanotechnology. In both popular treatments as well as policy documents, quotations from it are rampant while Feynman's authorship serves as a rhetorical anchor to scientific authority. This critical linkage was strengthened by the fact that Feynman later shared the Nobel Prize for his research on theoretical quantum electrodynamics. According to what some have appropriately called the 'standard story' of nanotechnology, Feynman presented the crucial initial vision of the innovative nano-research that scientists could do, the achievement of which only required the proper tools. ${ }^{23}$

These tools - namely new and improved electron microscopes-were incrementally developed by scientists and engineers during the 1960s and 1970s. This led to the next milestone in the 'standard story' that helped set the stage for the eventual promotion of a national nanotechnology initiative. In 1986, Gerd Binnig and Heinrich Rohrer, researchers at an IBM research laboratory in Zurich, received the Nobel Prize for their design of the scanning tunneling microscope. With a properly functioning instrument (the achievement of which is still something of a black art), researchers now had the ability to 'see' individual atoms as their probe scanned a sample's surface and rendered an image of its topology on a computer screen. ${ }^{24}$

Now able to image atoms, the next milestone in realizing Feynman's now-mythic vision was the ability to move them. In a 1990 paper published in Nature, two researchers reported that they had manipulated individual xenon atoms on the surface of a single crystal of nickel cooled to almost absolute zero with 'atomic precision. ${ }^{25}$ In their demonstration of the ability to 'fabricate rudimentary structures of our own design,' 
Eigler and Schweizer honored their corporate sponsor by using 35 xenon atoms to spell 'IBM.' A major article in The New York Times followed in which a reporter described how he laboriously moved about a few atoms with Eigler's coaching. ${ }^{26}$ Engineering at the nanoscale, as the Times described it, was not only potentially ground breaking but entertaining — as Eigler wrote in his 1989 lab notebook entry, 'I am really having fun!'

Stunts like this made international headlines and provided the capstone to Feynman's roadmap-in principle, researchers could now organize matter as well as see at the atomic level. However, doing so was still a challenging enterprise that required a good deal of expensive equipment, tacit knowledge, and specialized skills. ${ }^{27}$ While a new community of electron microscopists coalesced around the new tools and techniques in the late 1980s and early 1990s, much of this happened out of sight from the larger scientific community and the general public. Another element, one that Feynman did not account for, was needed: a messenger to boldly proselytize for nanotechnology.

In the 1980s, K. Eric Drexler emerged as the most visible and vocal proponent of nanotechnology and its transforming potential. Born in 1955, Drexler attended MIT and, while working at that school's Space Systems Laboratory, wrote a 1981 paper that outlined his early vision for nanotechnology. ${ }^{28} \mathrm{He}$ argued that the ability to design protein molecules could lead to the manufacturing of molecular machines that, in turn, could make 'second-generation machines' and the 'construction of devices and materials to complex atomic specifications. ${ }^{29}$ Drexler went on to teach the first university course on nanotechnology, published an equation-laden textbook on the subject, and was a co-founder of the Foresight Institute, a non-profit group devoted to promoting the benefits of nanotechnology.

The first full articulation of Drexler's nano-utopia was his 1986 book Engines of Creation. Written for the general public, Drexler's book considered the potential benefits and risks arising from the wholesale production of nanomachines. ${ }^{30}$ At the heart of his vision was what Drexler called 'assemblers,' hypothetical autonomous machines, protein-sized or smaller, that could produce virtually any material or object. Such ideas were incorporated by science fiction writers who imagined a future in which a person had access to a 'utility fog' from which they could call forth the material necessities of life. While skeptical, one review of Drexler's book described it as a 'hopeful forecast, remarkable for an unembarrassed faith in progress through technology. ${ }^{\text {, }}$

A full treatment of Drexler's activities and the attention they received is beyond the scope of this paper. It will suffice to say that a 1991 article in Science called Drexler 'the apostle of nanotechnology' and noted that he was already a lightning rod for praise as well as vitriolic scorn from fellow scientists. ${ }^{32}$ Criticisms came from both science journalists and other researchers, with the detractors claiming that Drexler's vision of self-assembling nanomachines not only drew attention (and possibly funding) from actual lab-based endeavors but also would violate basic laws of conservation. ${ }^{33}$ Referring to Drexler's missionary zeal and the fervor he inspired among his supporters, one critic said, 'You might as well call it nanoreligion.' 34

However, for the sake of promoting research and development of nanotechnology to the top of the national agenda, Drexler and other nano-advocates performed an important function. In promoting radical futurist scenarios, which his critics placed in 
the realm of fiction rather than science, Drexler and his colleagues brought nanotechnology to the attention of policy makers. As such, Drexler and company may be considered the vanguard of a wave that eventually brought potent government support for more conventional and staid research programs devoted to nanotechnology. This was not long in coming.

In June 1992, Senator Albert Gore, recently returned from the United Nations Earth Summit in Rio de Janiero, convened a congressional hearing devoted to 'New Technologies for a Sustainable World. ${ }^{35}$ Drexler was one of the witnesses invited to appear before Gore's subcommittee. He testified that 'molecule-by-molecule control,' which nanotechnology suggested, could become 'the basis of a manufacturing technology that is cleaner and more efficient than anything we know today.' Nanotechnology, Drexler argued, certainly met 'the criteria for an environmentally critical technology.,36 Gore, for his part, displayed great enthusiasm for Drexler's ideas and his knowledgeable reference to Feynman's 1959 speech also confirmed that nanotechnology's creation myth still possessed great currency. ${ }^{37}$

Like many predictions of technological utopias, Drexler's congressional testimony says more about contemporary circumstances than it makes accurate statements about the future. Drexler's pronouncements resonated with concerns held by American politicians and the public about the environment, sustainable development, and American economic competitiveness. It depicts a future ameliorated and achieved through the adoption of a 'technological fix,' one where nanotechnology would raise 'the material standard of living worldwide, while decreasing resource consumption and environmental impact. 38

Drexler's appearance marked the most visible discussion yet on Capitol Hill of nanotechnology as a potentially valuable area for federal investment. Topics that politicians care most about—health, the economy, and national security—all looked to benefit from nanotechnology. While yet a minor blip, nanotechnology was now on the federal government's radar screen.

\section{Planting the Flag}

The utopian nano-futures portrayed by Drexler and others garnered a great deal of attention in the early 1990s, and the claims could be quite extravagant. In 1995, a nanoenthusiast claimed that nanotechnology could even produce immortality. ${ }^{39}$ Consequently, many scientists and science writers were skeptical if not openly derisive and hostile toward such visionary claims. In his review of the book Nano! Remaking the World Atom by Atom, chemist David E. H. Jones, for example, concluded that until scientific questions surrounding the most optimistic claims of nano-enthusiasts were answered, nanotechnology itself would 'remain just another exhibit in the freak-show that is the boundless optimism school of technical forecasting. ${ }^{40}$ Perhaps more seriously, other critics noted that advocates who promised great benefits from nanotechnology and drew on Feynman's reputation for their scientific authority were squandering the political and social capital accumulated by real scientists who were doing actual laboratory work. ${ }^{41}$ 
Scientists were clearly expending a great deal of effort to establish distinct boundaries between what they saw as legitimate research and nano-visions that seemed to have more in common with science fiction than laboratory realities. ${ }^{42}$ In order to gain access to the resources, i.e. funding from the federal government and industry they believed necessary to pursue a full-scale research program in nanotechnology, a compelling vision for nanotechnology needed to be articulated by people not on the fringe of the research establishment.

Mihail C. Roco was a key person who took the stage in the mid-1990s determined to strip nanotechnology of its exaggerated claims and to promote an ambitious, realistic nano-research program as a national priority. Born in 1947 in Bucharest, Roco was a mechanical engineer who came to the USA in 1980, where he carried out research at a number of institutions before joining the National Science Foundation (NSF) in 1990. 'Captivated by the unity and coherence encountered in nature,' Roco wanted to likewise promote the 'coherence of science and technology. ${ }^{43}$ Soon after joining the NSF, he helped create a new, modestly funded program that investigated the synthesis of nano-sized particles. ${ }^{44}$ Gradually, Roco began to lay the foundation for a much more ambitious inter-agency program that would support a whole range of research in nanotechnology. 45

Roco launched his entrepreneurial plans at a promising time. Following the end of the Cold War, there was much debate among scientists, policy makers, and government agencies about how to restructure US science policy. There was general agreement that that US science policy needed revision yet achieving consensus on how best to do this was difficult. National defense against a monolithic Communist threat no longer served as sufficient justification for funding basic science. Just as significantly, the end of the Cold War signaled to policy makers that the next arena of conflict would be in the global marketplace in the form of increased economic competition from European and Asian countries. ${ }^{46}$ This was an especially salient fact to US lawmakers who read reports of how Japanese and European companies were taking the basic research done in American laboratories to the global marketplace and profiting handsomely in the process. In 1991, Japan's Ministry of International Trade and Industry pledged some US\$225 million for nanotechnology, with research aimed at benefiting that country's electronics industries. ${ }^{47}$ News like this fed existing fears among corporate and government leaders that the US was falling behind in a potentially key economic area and spurred more calls for a revamped national science policy in the wake of the Cold War.

Articulating an appropriate policy to deal with this competitive threat from abroad became a priority for lawmakers and policy analysts. More than half a dozen major reports appeared that suggested how to re-structure US science policy in response to the new global environment. ${ }^{48}$ Solutions included improving America's publicly funded research infrastructure and investing public monies in technologies whose benefits were only on the horizon. While not named as such, advocates soon touted nanotechnology as one of these under-supported fields with great potential. Many of these suggested changes were embraced in the first official review of US science policy in the post-Cold War era. Science in the National Interest, released in 
August 1994, described basic research and technological development not as the keys to national security but as elements that 'underpin the nation's economy.' Gore stated, in words reminiscent of Vannevar Bush's half-century old vision, 'Technology is the engine of economic growth; science fuels technology's engine. ${ }^{49}$ US science policy, the report said, should enhance connections between fundamental research and national goals and one of these goals was, of course, long-term economic growth.

Compared with the structured plans put forth by the Japanese, the US effort in nanotechnology was under-funded and disorganized. For example, since 1978, the NSF had funded the National Nanofabrication Facility at Cornell University. ${ }^{50}$ The US\$40 million facility served as a place where researchers from around the country could come to do research and use equipment their home institutions lacked. The National Institute of Standards and Technology also began an initiative in nano-research. Given these disparate initiatives, which in toto were spread over 12 different agencies, Roco and others claimed that the US lagged behind other countries when it came to a major national investment in nanotechnology. ${ }^{51}$

As a first step in coordinating the people, infrastructure, and funding for nanotechnology research in the US, Roco, along with Richard Siegel (Rensselaer Polytechnic Institute) and Evelyn Hu (University of California at Santa Barbara), organized a workshop in Arlington, Virginia. This 1997 meeting was held under the auspices of the World Technology Evaluation Center (WTEC), formerly known as the Japanese Technology Evaluation Center. Charged with examining foreign research in selected technology areas and operated out of Loyola College in Baltimore in cooperation with the NSF, WTEC provided information for policy makers concerned about American industrial competitiveness.

The WTEC meeting marked the beginning of an effort to ascertain research trends in nanotechnology worldwide. ${ }^{52}$ Roco claimed that nanotechnology was at 'a level of development comparable to that of computer/information technology in the 1950s' yet was poised-with sufficient funding - to become a key emerging technology for the 21 st century. ${ }^{53}$ At the meeting, attendees described the current level of US spending on nanotechnology-in fiscal year 1997, this was US\$115 million with more than half of the money coming from the NSF-and emphasized the need for interagency collaboration. The report Roco and his colleagues prepared also noted that governments in Japan and Europe were already funding comprehensive programs. ${ }^{54}$ However, compared to the far-reaching and visionary claims by Drexler and other nano-utopians, the soberly written WTEC report served to clarify the current state of nanoresearch rather than promote nano-utopian visions.

After the May 1997 meeting, Roco helped form an Interagency Working Group on Nanoscience, Engineering, and Technology (IWGN) which he chaired. The IWGN answered to the cabinet-level National Science and Technology Council established by President Clinton in 1993. Throughout 1998, the IWGN met and worked out a vision for what ultimately became the National Nanotechnology Initiative. Like all major government initiatives, putting the pieces in place took a great deal of time and coalition building. 
While Roco and his colleagues were formulating their proposal for the NNI, the US government reviewed its investment in scientific research yet again. In February 1997, soon after the second Clinton administration began, House Speaker Newton L. Gingrich asked the House Committee on Science to develop a long-range science and technology policy. The committee's report, released in September 1998, reaffirmed that, with the end of the Cold War, the principal contributions of science and technology would not be for national defense but economic competitiveness. ${ }^{55}$ As Gingrich framed it, 'the competitions we are engaged in now are less military and largely economic. ${ }^{56}$

The 1998 report also articulated aspects of America's new 'mega-era' of science policy that advocates of the National Nanotechnology Initiative soon embraced. ${ }^{57}$ Grants to individual scientists and engineers were the 'primary channel by which the government stimulates knowledge-driven basic research,' while the research done at universities and national laboratories must be continually 'applied to the development of new products or processes,' so as to further strengthen linkages between university laboratories and commercial ventures formed after the passage of the Bayh-Dole Act in $1980 .{ }^{58}$ Just as significantly for the success of the NNI, the report acknowledged that private industry was unlikely to fund areas like nanotechnology that had no foreseeable practical application; this role would therefore devolve to the federal government.

As members of Congress re-examined national science policy, several prominent people joined the campaign for a national nanotechnology effort. At this point, as the push for the NNI's funding intensified, the first noticeable traces of nano-utopian visions crept into the rhetoric of scientists and administrators. In April 1998, Neal Lane, President Clinton's science advisor, appeared before the House Basic Research Subcommittee. Lane, whose specialty was theoretical atomic and molecular physics, made a statement that was to be widely quoted: 'If I were asked for an area of science and engineering that will most likely produce the breakthroughs of tomorrow, I would point to nanoscale science and engineering. ${ }^{59}$ Noting how NSF support had enabled nanotechnology to transform 'from the realm of science fiction to science fact,' Lane went on to describe ideas that drew as much from the former as the latter: nano-sized medical probes, new classes of materials, and-straight from Drexler's writings'nanomanufactured objects that could change their properties automatically or repair themselves.' As Lane put it, the 'possibilities of nanotechnology are endless.'

On 11 March 1999, Roco formally presented plans for the National Nanotechnology Initiative to Neal Lane and Thomas Kalil, Clinton's Deputy Assistant for Technology and Economic Policy. During their two-hour meeting, Roco described an initiative for fiscal year 2001 costing some US\$500 million. At the end of the meeting, nanotechnology won out over competing initiatives and now had two well-placed advocates in the White House.

According to Roco, the next task was to educate both the public as well as Congress as to what nanotechnology was and what it could offer. A glossy brochure entitled Nanotechnology: Shaping the World Atom by Atom made the case to the public and drew upon nano-utopian rhetoric that was rapidly becoming de rigueur - the vision of Feynman's 1959 talk, the progress made in manipulating atoms via electron 
microscopy, the potential to fabricate nanoscale electronic devices, the now-famous IBM logo writ in xenon atoms, and the vast commercial and societal benefits that investment in the NNI could open up. ${ }^{60}$

Congress still required persuading, however. On 22 June 1999, the House of Representatives' Committee on Science met to review the federal government's support of nanotechnology and to discuss its potential economic implications. Chairman Nick Smith opened the meeting by noting that the United States did not dominate nanotechnology. 'How much effort,' he asked, 'should the Federal Government be putting into tax-payer funded research in this area?'61

Several witnesses answered Chairman Smith; all drew in some capacity upon the utopian visions of nanotechnology's potential that had been gestating for over a decade. Of those who spoke that afternoon, chemist Richard E. Smalley of Rice University was perhaps most persuasive. Smalley was a co-discoverer of carbon-60 molecules, better known as 'buckyballs,' for which he had shared the 1996 Nobel Prize. Buckyballs were closely related to carbon nanotubes that Japanese scientists had discovered in 1991, and advocates of nanotechnology referred to these new structures as clear examples of how matter could be deliberately controlled at the atomic level.

'There is a growing sense in the scientific and technical community,' Smalley told Congress, 'that we are about to enter a golden new era. ${ }^{62}$ Citing his own experience battling cancer, Smalley connected research at the nanoscale with an array of societal benefits that could result, including medical breakthroughs. The Nobel laureate shrewdly pointed out that research in nanotechnology was 'intrinsically small science.' Because research in nanoscience was not centralized in one or two national laboratories, funding the NNI would combat the trend towards 'Big Science,' offering a way to fund individual researchers. Funding 'small science' (in both senses) would, Smalley argued, help attract students into science careers just as Sputnik's launch in 1957 had inspired his generation.

The NNI, Smalley avowed, would also support broader national policy goals. 'There's this immediacy between the ivory tower pure scientist and the technologist' in nano-research, Smalley said, and the NNI would simultaneously strengthen both while creating valuable linkages between basic research and commercial applications. ${ }^{63}$ Nanotechnology, Smalley concluded, presented a 'tremendously promising new future.' What was needed was someone bold enough to 'put a flag in the ground and say: "Nanotechnology, this is where we are going to go ...". 64

In urging Congress to fund a major national initiative for nanotechnology, advocates of the NNI deployed an array of effective arguments, some new and some already familiar: the specter of economic competition with Europe and Japan; the opportunity to recruit a new generation of scientists and engineers; and support for traditional individual, peer-reviewed research rather than giving a handout to a few giant national laboratories. Persuasive utopian images and frontier metaphors were added to the rhetorical brew. One witness that afternoon, for example, compared nanotechnology with Kennedy's declaration to put a man on the moon. ${ }^{65}$ What the USA needed to do, advocates insisted, was to be bold once again and plant a flag on a new frontier. 


\section{The Floodgates Open}

Richard Smalley and the others who testified in June 1999 were largely pushing against an open door as they made their case for a major national investment in nanotechnology. Reflecting new ideas in circulation about national science policy, questions from congressional representatives were more praising of nanotechnology than they were probing. Such enthusiasm is understandable as the House committee that heard Smalley and others was convened to gather information, not appropriate tax-payers' money. Congressional questioning would become more intense once real dollars were at stake.

Roco and other NNI advocates focused their efforts next on federal agencies such as the NSF, NASA, and the Department of Defense, which would likely administer funding for a major new initiative. By November 1999, the Office of Management and Budget and the White House were studying plans for the NNI. That same month, the Presidential Council of Advisors in Science and Technology (PCAST) issued its formal review of the proposed NNI. ${ }^{66}$ More circumspect in its espousal of the now-familiar utopian predictions for nanotechnology, PCAST nevertheless identified nanotechnology as a potential path to a 'new industrial revolution,' one that might lead to unforeseen advances in 'materials and devices of all sorts ... medicine and health, biotechnology and agriculture, as well as national security. ${ }^{36}$ In an increasingly familiar comparison, nanotechnology was likened to the state of solid-state physics research in the 1950s but, unlike the lead that America enjoyed in transistors and microchips when their commercialization began, the USA lacked 'an early lead in nanotechnology.' PCAST argued that the USA could not afford to be in second place: 'The country that leads in discovery and implementation of nanotechnology will have great advantage in the economic and military scene for many decades to come.' The NNI, therefore, represented an opportunity to swiftly create an infrastructure for nano-research and perhaps avoid the precarious state the USA found itself in during the 1980s when fears of Japanese technological supremacy ran rampant. A subsequent letter from the PCAST to President Clinton offered firm and clear support of the NNI. ${ }^{68}$

With these endorsements in hand, President Clinton traveled to Pasadena, California where he addressed a standing-room only crowd at Caltech's Beckman Auditorium. On 21 January 2000, Clinton articulated the need to strengthen America's investment in science and technology. After paying homage to Caltech and Feynman (as well as an image suspended above him of the Western Hemisphere constructed with individual gold atoms), Clinton announced the inclusion of a US\$2.8 billion 'Twenty-First Century Research Fund' in his 2001 budget, which was an element in a larger strategy to double the NSF's budget over the next five years. A 'top priority' was a major increase in the NSF's funding for nanotechnology-over 124\% or US\$227 million in the next year alone-which, when combined with funding for other agencies, would nearly double the federal investment. Clinton rhapsodized

Just imagine, materials with 10 times the strength of steel and only a fraction of the weight; shrinking all the information at the Library of Congress into a device the size of a sugar cube; detecting cancerous tumors that are only a few cells in size. Some of these research 
goals will take 20 or more years to achieve. But that is why—precisely why ... there is such a critical role for the federal government. ${ }^{69}$

A major Presidential address now incorporated aspects of the utopian views suggested by Drexler and adopted by science managers. Returning to Washington, DC on Air Force One, Neal Lane and NSF Director Rita Colwell reiterated the promise of nanotechnology for reporters. According to Lane, 'nanotechnology may not be something that everybody talks about every day, but they will, because it's really the whole next generation in manufacturing. ${ }^{70}$ Not surprisingly, Colwell and Lane praised the speech and predicted wide bipartisan support of the President's plan. In fact, just a few months before Clinton's speech, an editorial in The Washington Post by former House Speaker Gingrich claimed nanotechnology would 'have as big an impact on our lives as transistors and chips did in the past 40 years' and called for a substantial increase in federal support for science. ${ }^{71}$

Despite the utopian gloss advocates could put on the importance of nanotechnology to national needs, the annual appropriations process grounded the American nanotechnology initiative to more prosaic political and budgetary struggles. Initial congressional response to the NNI was positive. At a Senate roundtable discussion in April 2000, Senator Evan Bayh, who twenty years earlier co-sponsored the Bayh-Dole Act that helped re-shape the relationship between universities and the federal government, called nanotechnology 'extremely important to future rates of innovation' and the overall economy in the USA. ${ }^{72} \mathrm{He}$ and several of his colleagues heard presentations from Richard Smalley as well as Donald Eigler of IBM. Improvising on his earlier testimony, Smalley noted how basic sciences like physics and chemistry were at the core of nanotechnology. A vote for the NNI was, in effect, a vote for basic science research and education. ${ }^{73}$

As spring arrived in Washington, it became clear that the science advocates would not secure funding for the NNI without a struggle. Concerns over the NNI centered around several issues. Some Republican lawmakers warned that Roco's multi-agency plan would be hard to manage and result in a duplication of research. The NNI lacked, one congressman complained, 'a clear strategy to ensure coordination within the government. ${ }^{74}$ Meanwhile, a non-partisan report from the Congressional Research Service noted that, as 'nanotechnology was still in its infancy,' large-scale practical applications were at least a decade away. ${ }^{75}$ Finally, those lobbying congress to double the entire NSF budget opposed any funding for the NNI that came from research programs already established.

In May 2000, the Senate subcommittee that controlled appropriations for both NASA and the NSF met. Senator Christopher Bond, the panel's chair, expressed doubts not about the NNI's value per se but about how the NSF would manage the rapid infusion of funding. ${ }^{76}$ The Missouri Republican told NSF officials to 'count me skeptical' about multi-agency initiatives like the NNI and asked the agency to clarify how it would allocate the requested increase in funds for nano-research. Bond's minority counterpart, Senator Barbara Mikulski of Maryland, expressed her own worries about allocating monies to the NNI without any kind of long-term plan. As she told Lane and Colwell, nanotechnology seems 'like our little secret ... we need visibility.' 
A few weeks before the Senate hearing, nanotechnology did indeed receive greater visibility, although not the kind its advocates wanted. In April 2000, the technology magazine Wired published an article by Bill Joy called 'Why the Future Doesn't Need Us. ${ }^{77}$ Joy, one of the co-founders of Sun Microsystems, could not be dismissed as a neo-Luddite. In warning about future technological dystopias, Joy singled out nanotechnology-especially the Drexlerian visions of autonomous and self-replicating nano-assemblers - as a potential threat to humanity. Joy's article became especially infamous for highlighting the 'grey goo' problem, the idea that uncontrolled self-replication by nanomachines might destroy entire ecosystems and threaten what it meant to be human. In contrast to the utopian views of Drexler or the more attainable goals Roco and other NNI supporters proposed, Joy, writing as a 'skeptical nanoist,' sounded the tocsin for a decidedly dystopian vision of a nano-future and urged a moratorium on further research. ${ }^{78}$

Nano-advocates recognized the potential danger opponents like Joy posed. Just as utopian visions can generate public support and shape favorable policy, dystopian ones can derail them. At the May 2000 Senate hearing, Senator Bond remarked on the 'hysteria and fear' already surrounding genetically modified foods and it was easy for nano-advocates to imagine a similar public reaction to nanotechnology. ${ }^{79}$ There is no direct evidence that Joy's concerns influenced congressional debate of the NNI in the summer of $2000 .{ }^{80}$ Furthermore, Joy did not represent the dominant view of industry. According to one participant in the establishment of the NNI, a 'critical factor' in the selling of the NNI in the summer of 2000 was the vocal support industry representatives, especially those in the semi-conductor business, gave on the Hill. $^{81}$

Over the summer of 2000, these lobbying efforts paid off as a swell of bipartisan support for the NNI swept away concerns, fiscal, dystopian, or otherwise. Maryland's Senator Mikulski, renowned in science circles as a staunch advocate of NASA, jumped on the utopian bandwagon. In a speech at NASA headquarters in June 2000, Mikulski told her audience that 'we are on the verge of a new revolution-the nanotechnology revolution' and urged her colleagues to support the NNI, one of the 'least noted and most important documents of the Clinton administration. ${ }^{82}$ Across the senate aisle, Republican Senator Trent Lott praised nanotechnology in a letter to his colleagues on the Senate Appropriations Committee. Lott hailed the NNI not so much for its utopian potential but because the national research infrastructure it would help create might be based in regions like Lott's home state of Mississippi, which traditionally received few federal research dollars. ${ }^{83}$

At the end of the summer, Roco's committee formally unveiled its proposal for the NNI, now honed by months of fine-tuning. The National Nanotechnology Initiative: The Initiative and its Implementation Plan requested US\$495 million-US\$150 million of which the NSF would dispense-to expand research at the nanoscale. ${ }^{84}$ At the heart of the interagency plan was an increase of some US\$90 million for basic research to fund individual scientists and small teams. This was a major increase, up about 50\% from the previous fiscal year to US\$177 million. While defined as 'research leading to new fundamental understanding and discoveries,' the proposal clearly tied this 
research to the 'capacity to create new affordable products with dramatically improved performance.' 85

The report also identified several 'Grand Challenges,' broad areas of research targeted for interagency funding. ${ }^{86}$ These included creating new nanostructured materials, nanoelectronics, and bio-nanosensors and linked basic science and engineering to ambitious, long-term economic goals. Congress directed the remaining money to construct a national infrastructure with 'centers of excellence' where nano-researcher would work with the stated goal of producing new discoveries to be 'rapidly commercialized by industry. ${ }^{87}$

After last-minute political wrangling, Congress approved budgets for the NNI's various agencies in the fall of 2000 . Some US $\$ 465$ million of federal money was directed to fund the NNI, representing a $72 \%$ increase in the national investment in nanotechnology compared to the previous year. ${ }^{88}$ Several states followed suit. California, with $12 \%$ of the US population and the world's fifth largest economy, has frequently been on the leading edge of new technological developments. In late 2000, then-Governor Gray Davis approved a US\$100 million state initiative to foster nanotechnology in California: 'It's my hope,' Davis explained, 'to replicate Silicon Valley. ${ }^{89}$

The overall funding profile for the national investment in nanotechnology is shown in Figure 1. Three important facts stand out. In the span of little more than half a decade, nanotechnology advocates like Roco and two different administrations had increased national funding for nanoscale science and engineering by some $850 \%$. Second, the NSF and the Department of Defense control the largest amounts of NNI funding and the relative amounts of money going to civilian versus defense-related research in nanotechnology reflect changing national priorities after the September 11 attacks. Finally, national enthusiasm for nanotechnology, at least in terms of budget allocations, only increased after George W. Bush was selected President in 2000. The new Republican administration generously supported nanotechnology, acting in part on the belief that the nascent field would contribute significantly to national security. ${ }^{90}$ On 3 December 2003, Bush signed the '21st Century Nanotechnology Research and Development Act' which authorized US\$3.7 billion more for nano-research over the next four years. ${ }^{91}$ If one accepts the premise that budgets reflect policy, any doubts about nanotechnology's place as the first 'boom science' of the 21 st century or immediate concerns about environmental or societal consequences were swept away by the flood of money that began pouring into universities and national laboratories in $2001 .^{92}$

\section{Nano-Boom or Gloom?}

It is too soon to judge the effects the NNI may have on society, industry, or the scientific community. Indeed, one might even hesitate to call nanotechnology a full-fledged 'technology' as so very few of the devices that advocates had envisioned have materialized. Furthermore, nanotechnology has yet to infiltrate public awareness fully, as a recent poll indicated. ${ }^{93}$ However, we can try to understand the reasons and rationales that prompted lawmakers to direct vast sums of taxpayer dollars to support a realm of technoscience that retains strong links to fiction as much as facts. 
The NNI emerged at a salient point in US history. In the late 1980s and throughout the 1990s, economic competitiveness replaced the twilight military struggle of the Cold War, and science advocates could no longer claim national defense as the prime rationale for funding basic research. Lawmakers were still struggling to adapt national policies to the new global environment and to the implications of the increasing commercialization of science. Advocates of the NNI proposed it at a propitious timebetween the end of the Cold War and a renewed preoccupation with national security after 11 September 2001-when lawmakers were trying to reshape national science policy.

One recent analysis correctly situates the NNI in the period of 'post-academic' science. ${ }^{94}$ This regime is characterized by an emphasis on the utility of science and the enlistment of academic research as a 'wealth-creating technoscientific motor for the whole economy,' views clearly expressed in the documents and testimony supporting the NNI. ${ }^{95}$ While the end of the Cold War is certainly relevant, the changing nature of research funded by the federal government and conducted at universities is even more significant. Since the passage of the Bayh-Dole act in 1980, the 'triple helix' of relations between the academy, industry, and government has been significantly altered and strengthened. ${ }^{96}$ The borders between science and technology, as the NNI implementation plan shows, have blurred while the commercialization of academic science has become a key driver for its funding.

The favorable timing of the NNI only partly accounts for its success. It cannot explain fully the justifications deployed in support of a major new initiative that would benefit science, technology, and industry. As we have seen, nano-advocates presented an array of heterogeneous arguments to Congress and the public. Despite the new period of 'post-academic science,' many of these justifications were framed in familiar ways. They included the appeal to national competitiveness, introduced in the 1980s in the face of Japan's economic success, and the need for America to 'plant a flag,' as did the Apollo astronauts, on the cutting edge of a new technology. While American scientists claimed two-thirds of the 1996 Nobel Prize for their discovery of buckyballs, such honors did not ensure that the USA would reap commercial benefits from them. That Japan and Europe had or were planning major government programs for nanotechnology allowed advocates of the NNI to argue that it was imperative that the USA do likewise.

Congressional witnesses predicted that nanotechnology would draw American youth into science, a rationalization for science funding that dates to the Sputnik era at least. Chemist Richard Smalley reached back even further in time in his testimony, claiming that nano-research as 'small science' was a way for the individual scientist to do more personal research commensurate with the days of sealing wax and string, and after September 11, national security, the major rationale for so much Cold War-era research and development, emerged once again as a major justification for funding nanotechnology. ${ }^{97}$

The NNI also offered lawmakers and science managers an opportunity to revitalize areas of research they saw as under funded during the 1990s. Clinton's announcement in 2000 of major federal support for nanotechnology, for example, was part of a larger 
strategy to significantly increase the NSF's budget and an opportunity for physics, chemistry, and engineering to regain lost ground due to stagnant budgets during the 1990s. The NNI, one editorial noted, 'may prove to be one of the most brilliant coups in the marketing of basic research' since Nixon announced the 'War on Cancer.'98 However, while the public could understand the necessity of research on cancer, the NNI relied on strategic and utopian marketing to enable its success.

Indeed, one can question whether the NNI is really even science policy per se. After leaving the NSF, Neal Lane, one of the advocates for the NNI inside the White House, admitted that the NNI was actually much more a technology policy and those who advocated the applications (as opposed to the fundamental knowledge) enabled by nano-research had won the day. ${ }^{99}$ The NNI funded the basic research that advocates like Smalley called for, but much of this was directed toward specific commercial applications and national goals. ${ }^{100}$

Finally, one must acknowledge the energy that entrepreneurial science managers like Roco invested in crafting a policy and plan for the NNI. As Roco explained, the NNI was 'prepared with the same rigor as a science project between 1997 and 2000: we developed a long-term vision for research and development.' ${ }^{101}$ These efforts succeeded in winning over lawmakers initially skeptical of a complex multi-agency effort as well as the NSF's ability to manage a major infusion of funds.

One can compare the success the NNI had with other major research initiatives. Opponents of the ill-fated Superconducting Supercollider, for example, criticized it as a mega-project that would benefit a small and elite research community as well as a single state (Texas). ${ }^{102}$ In comparison, the NNI's funding was not earmarked for a single project, discipline, or region. Many parts of the country would presumably benefit from Congressional support for the NNI and the research monies would benefit a large number of researchers in both the life and physical sciences. In this sense, the organization and funding of the NNI was a decentralized form of federally supported Big Science similar to the Human Genome Project. Advocates for both claimed the programs would foster pluralism and decentralization in science as well as local investments and research initiatives. ${ }^{103}$ The establishment of national policies for nanotechnology also resembles the rush to fund research in high-temperature superconductivity in the late 1980s. Descriptions of levitating trains, medical breakthroughs, and robust economic competitiveness all spurred federal and commercial investment in fundamental research conducted with an eye toward future applications from the outset. ${ }^{104}$

Overshadowing all of these rationales are two meta-reasons, both familiar and suspect to historians of technology, which also help account for the success of the NNI. While technological determinism may be out of fashion with scholars, nano-advocates regularly made arguments employing various shades of it. A typical line of reasoning invoked Moore's Law (which states that the computing power on a microchip doubles roughly every 18 months) and described the emergence of economic crises once engineers reached the physical limits of what was possible with microtechnologies. ${ }^{105}$ Indeed, industry advocates used the seeming end of the technological improvements described by Moore's Law to push for the NNI. ${ }^{106}$ This depiction of technological inevitability arose from nothing more than what experts claimed was the 'natural' 
development of computing technology. Advocates presented nanotechnology as one way to avert these limitations. ${ }^{107}$ Indeed, according to some enthusiasts, revolutionary developments at the nanoscale were themselves inevitable, yet another phase in human mastery over nature. ${ }^{108}$

Even more powerful as a motivating force were predictions of the utopian benefits nanotechnology could bring to American society and the economy. Visions of tomorrow that Roco, Smalley, and others successfully presented-which themselves tapped into Richard Feynman's mythic vision of nanotechnology's potential and the futuristic, sometimes outlandish, ideas put forth by people like Drexler-attracted and excited lawmakers. With the end of the Cold War and lawmakers' continued interest in economic competitiveness, nanotechnology offered to reshape, literally, how our world was constructed. As David Nye has pointed out, American narratives of technological utopias come in a variety of categories: natural where technologies are a natural outgrowth of society; ameliorative in which new machines improve everyday life; and transformative in which technologies reshape social reality. ${ }^{109}$ Nanotechnology appears as a hybrid example as advocates drew upon elements from all three narratives in their lobbying efforts.

While the most extreme scenarios of a future made better through nanotechnology originated with people like Drexler, who operated at the vanguard (and sometimes the fringe) of nanotechnology, they were embraced and repackaged by mainstream science managers and renowned researchers. Mihail Roco and his colleagues described nanotechnology with an exuberance that matched the prognostications of Drexler and his allies. ${ }^{110}$ Roco promoted the coming convergence of nanotechnology with biotechnology, information technology, and cognitive science ('Nano-Bio-Info-Cogno' in policy jargon), which could produce a 'golden age ... an epochal turning point in human history.' As expressed, 'If the Cognitive Scientists can think it, the Nano people can build it, the Bio people can implement it, and the IT people can monitor and control it. ${ }^{111}$ Fully espousing an understanding of history predicated on an unshakable belief in technological progress, the funding of nanotechnology put humanity 'at the threshold of a New Renaissance of science and technology.' 112 Whether this convergence is indeed real or whether it represents another phase in the marketing of nanotechnology is yet to be seen. ${ }^{113}$

Visions of a future enabled and ennobled by nanotechnology share many common themes with scenarios presented by advocates of nuclear power, space exploration, and genetics technology. For example, supporters of nuclear power claimed that it would leave practically no part of society unimproved. Funded by the federal government and viewed with fear and fascination by the public, advocates presented the power of the nucleus as the solution to a host of economic, social, and national security problems. By eliminating hunger, unemployment, environmental degradation, and the drudgery of housework, nuclear power promised 'dazzling possibilities of life, liberty and the pursuit of happiness.' 114 Outer space, meanwhile, offered Americans new frontiers to explore as well as endless research opportunities for scientists. ${ }^{115}$ Decades later, advocates of genetic engineering assured the possibility of disease prevention and therapy along with an improved understanding of what it meant to be human. Supporters of 
nanotechnology, deliberately or no, conflated these disparate utopian aspects. Nanotechnology could 'offer the opportunity to understand life processes ... cure and prevent disease, heal injured bodies, and protect society' all while providing more 'endless frontiers' for exploitation and exploration by scientists and entrepreneurs. ${ }^{116}$

Dystopian warnings, put forth initially by Joy and others, did not abate after the NNI was funded. If anything, the surge of new money directed toward nano-research and development fueled anxieties. ${ }^{117}$ Researchers spoke out publicly on the possible toxicity of newly designed nanoparticles and the insurance industry, still engaged in asbestos-related lawsuits, began to estimate litigation costs stemming from nanotechnologies. ${ }^{118}$ Politicians were also aware of a potential backlash against the initiative they had approved. At an April 2003 hearing on nanotechnology's societal effects, Vicki L. Colvin, director of the Center for Biological and Environmental Nanotechnology at Rice University, warned Congress that nanotechnology needed to avoid the 'wow-toyuck' arc that genetically modified organisms had taken. ${ }^{119}$ At the other end of the spectrum, Eric Drexler, arguably the most well-known and visionary advocate of nanotechnology's transformative potential, criticized the NNI for its timidity and business-as-usual funding strategy. Leaders of the NNI, Drexler charged, had neglected the original 'Feynman vision' of nanomachines because 'public concern regarding its dangers might interfere with research funding. ${ }^{120}$ Despite the ample and growing funding directed toward nanotechnology, debate over the trajectory its research and development would take remained robust and unsettled.

In the 1920s, visionaries like Henry Dreyfuss and Norman Bel Geddes believed that utopia could literally be designed and society thereby perfected. ${ }^{121}$ Advocates of nanotechnology expressed similar views; namely that the future could be crafted atom by atom. Whether future generations will look at predictions about nanotechnology's ability to re-shape the world with the same bemusement that the phrase 'energy too cheap to meter' draws remains to be seen. Nanotechnology remains as much a futuristic vision as an active area of real-life research and development. With the inevitable disappointments that almost always accompany predictions of technological utopias, one may wonder why they remain so attractive to scientists, lawmakers, and the public. As the history of nanotechnology continues to unfold, perhaps historians will address this question again and arrive at a more nuanced and specific answer. Until that time, a simpler explanation remains - visions of technological utopias, despite their dubious claims to success and the darker visions that accompany them, still sell and compel.

\section{Acknowledgements}

The research for this article was supported by a grant from the California NanoSystems Institute and National Science Foundation Grant SES 0304727 (as part of a Nanoscale Interdisciplinary Research Team Project). Several references cited in this article are available in on-line format only. Where this is the case, a URL link is provided and a hard copy of the document is in the author's working files. He wishes to acknowledge the assistance and suggestions of Nicole Archambeau, Larry Badash, Justin Bengry, Evelyn $\mathrm{Hu}$, John Krige, Kristen Shedd, and the anonymous reviewers. 


\section{Notes}

[1] 'Interview with Mihail C. Roco,' http://www.nano.gov/html/interviews/MRoco.htm.

[2] A second facility is being built at the University of California at Los Angeles. Almost all publications, regardless of audience, tend to use 'nanoscience' and 'nanotechnology' interchangeably with a strong preference for the latter and presumably more all-encompassing term. Despite the obvious historiographical conundrum this poses for the historian of technology, I have adopted this style except where I am explicitly referring to the actual scientific research on nanoscale phenomena and techniques.

[3] The White House, 'National Nanotechnology Initiative.'

[4] M. C. Roco, 'Broader Societal Issues,' Office of Science and Technology Policy, 'National Nanotechnology Initiative.'

[5] Roco, 'International Strategy.'

[6] Roco, 'Towards a US National,' 435.

[7] A nanometer (the prefix is the Greek word for 'dwarf') is one-billionth of a meter and an oftquoted unit of measurement cited in nanotech literature, the width of a human hair, is some 10,000 nanometers wide.

[8] Definition adapted from www.nano.gov, the official website for the National Nanotechnology Initiative.

[9] Barber and Freestone, 'An Investigation.'

[10] Horst Stormer quoted in Amato, Nanotechnology, 1.

[11] First quote from John Armstrong, formerly chief scientist at IBM, quoted on p. viii of Roco et al., Nanotechnology Research Directions;' second quote from Roco, 'The US National,' 6.

[12] Atkinson, Nanocosm.

[13] See, for example, the papers collected in Baird et al., Discovering the Nanoscale. The issue of patents is presented in Meyer, 'Patent Citation Analysis' while a view of potential risks is articulated in Swiss-Re, 'Nanotechnology' Risk Perception Series. See also Crow and Sarewitz, 'Nanotechnology and Societal Transformation;' Fogelberg and Glimell, Bringing Visibility to the Invisible. An example of the few articles with a focus on the history of nanotechnology include Johnson, 'The End of Pure Science?' which addresses policy issues and Mody, 'From the Topografiner' which discusses instrumentation.

[14] See, for example, Kingdon, Agendas, Alternatives, and Public Policies as well as papers in Sabatier, Theories of the Policy Process. See also Korsmo and Sfraga, 'From Interwar to Cold War' and Cook-Deegan, 'The Human Genome Project' for examples of how specific research programs were advocated.

[15] McCurdy, Space and the American Imagination.

[16] Sarewitz, 'Does Science Policy Exist?'

[17] See essays in Corn, Imagining Tomorrow, as well as the more recent collection by Sturken et al., Technological Visions.

[18] Feynman, 'There's Plenty of Room at the Bottom.'

[19] Ibid., 26.

[20] Feynman's 1959 talk appropriated ideas by science fiction author Robert Heinlein in his 1942 novella Waldo and, as Colin Milburn notes, nanotech's real origin can be argued to rest not with Feynman but in science fiction: Milburn, 'Nanotechnology.'

[21] A search of the World Wide Web in 2004 for the most popular web pages dealing with Feynman returned as many references to his 1959 paper as they did his Nobel prize. Also worth noting is the fact that the Foresight Institute, a non-profit organization devoted to promoting nanotechnology, annually awards a prize named after Feynman.

[22] Taniguchi, 'On the Basic Concept.' Taniguchi's term, used in a much different fashion from today, described precision machining of devices with tolerances less than a micrometer.

[23] Baird and Shew, 'Probing the History.' 
[24] Mody, 'From the Topografiner.' As Mody notes, scientists in the United States gradually adopted the STM in a variety of settings including corporate and national research labs as well as university departments. In 1986, the same year that Binnig and Rohrer won the Nobel Prize, Digital Instruments was founded in Santa Barbara, California and became the first company to market their version of an STM, the 'Nanoscope.'

[25] Eigler and Schweize, 'Positioning Single Atoms.'

[26] Siebert, 'The Next Frontier.'

[27] Mody, 'From the Topografiner.'

[28] Drexler, 'Molecular Engineering.'

[29] Ibid., 5278.

[30] Drexler, Engines of Creation.

[31] Monmaney, 'Nanomachines to Our Rescue.'

[32] Amato, 'The Apostle of Nanotechnology.'

[33] Stix, 'Waiting for Breakthroughs.'

[34] Amato, 'The Apostle of Nanotechnology,'1311.

[35] Science Committee on Commerce, Science, and Transportation, 'New Technologies for a Sustainable World.'

[36] Ibid., 21.

[37] Ibid., 30.

[38] Corn, 'Epilogue' and Drexler testimony in Science Committee on Commerce, Science, and Transportation, 'New Technologies for a Sustainable World,' 22.

[39] Du Charme, Becoming Immortal.

[40] Jones, 'Technical Boundless Optimism' which was a review of Regis's Nano!.

[41] Stix, 'Waiting for Breakthroughs.'

[42] The permeable boundary between science and science fiction is considered in Milburn, 'Nanotechnology.' Moreover, the efforts of scientists to delineate between 'real' science and the long-term visions put forth by people by Drexler stands as a classic example of boundary work; see, for example, Gieryn, Cultural Boundaries of Science.

[43] Roco, 'The US National,' 10.

[44] This was funded at about US $\$ 3$ million in 1991, a modest amount by NSF standards.

[45] A note on the funding process: The President's budget is typically submitted in January each year. In the US, new actions require a two-step congressional process-authorization and appropriation, two interdependent yet distinct activities. The actual allocation of money requires the prior passage of an authorization statute and the authorization process is done by a pair of committees, one in the House and one in the Senate.

[46] This was a point made in a number of studies including a report by the Council on Competitiveness called 'Science in the National Interest.'

[47] Crawford, 'Japan Starts a Big Push.'

[48] Boesman, 'Analysis of Ten Selected.'

[49] Office of the Press Secretary, 'White House Releases.'

[50] This was originally called the National Research for Submicron Structures; the name was changed in 1988. Six years later, the NSF funded the National Nanofabrication Users Network which expanded the Cornell model to four other schools.

[51] Roco, 'The US National,' 2.

[52] A report from the May 1997 workshop was later published; Siegel et al., WTEC Workshop Report on R\&D Status and Trends. According to one person involved in the process, some scientists were uncomfortable with the fact that Roco appeared to have already decided that the US presence in nanotechnology was not sufficient. Evelyn Hu, 4 January 2005 personal communication with the author.

[53] Ibid., 1.

[54] A follow-up report addressed the specific question of where the US stood in relation to Japan and Europe; Siegel et al., 'Nanostructure Science.' 
[55] House of Representatives Committee on Science, 105th Congress. 'Unlocking our Future.'

[56] Gingrich, 'February 12, 1997 letter.'

[57] According to the 1998 report, the pre-World War Two period was the first 'mega-era' of science policy while the US support of science and technology for national defense during the Cold War typified the second 'mega-era.'

[58] The Bayh-Dole Act encouraged the utilization of inventions produced under federal funding and promoted the participation of universities in the commercialization of ideas derived from basic research.

[59] Lane's 22 April 1998 testimony can be found on the web site for the House Committee on Science: http://www.house.gov/science/.

[60] Amato, Nanotechnology. What is unknown is how effective this campaign was or how many people it reached.

[61] House of Representatives Committee on Science, 'Nanotechnology,'1-2.

[62] Ibid., 7.

[63] Ibid., 21.

[64] Ibid., 12.

[65] Ibid., 10.

[66] Pres. George H. W. Bush established PCAST in 1990. It is a non-governmental advisory group formed without Congressional approval. Therefore, each President must renew the group's existence. President Clinton established his PCAST in November 1993 by executive order.

[67] This and subsequent quotes from the PCAST review; PCAST's review available at: http:// www.ostp.gov/PCAST/pcastnano2.html.

[68] 14 December 1999: http://www.ostp.gov/PCAST/pcastnano.html.

[69] William J. Clinton; 21 January 2000 speech. Text available at: http://pr.caltech.edu/events/ presidential_speech/pspeechtxt.html.

[70] Lane quote from Jones, 'Aboard Air Force One.'

[71] Jones, 'Former House Speaker Gingrich.'

[72] Leath, 'Administration and Congress.'

[73] Leath, 'Senate Science and Technology Caucus.'

[74] Southwick, 'Nanotechnology.'

[75] Davey, 'Manipulating Molecules.'

[76] Leath, 'NSF Hearing.'

[77] Joy, 'Why the Future Doesn't Need Us.'

[78] With apologies to Robert Boyle and his 1661 book The Sceptical Chymist.

[79] For example, the popular science fiction show Star Trek: Voyager featured a main character who could assimilate other life forms by injecting them with 'nano-probes.'

[80] Joy's article did encourage policy makers to stress the need to better understand (i.e., fund studies of) the environmental and societal risks of the nano-frontier. The article was also seen as a sufficient threat so as to warrant a response from John S. Brown, a researcher at Xerox PARC at a September 2000 conference the NSF convened to address the ethical and societal issues of nanotechnology; see Brown, 'Don't Count Society Out.' Glimell, 'Grand Visions and Lilliput Politics' discusses Joy's article and Roco's reaction-what Glimell calls 'doing the "Roco"-motion'-to it.

[81] Evelyn $\mathrm{Hu}, 4$ January 2005 personal communication with the author. More work clearly needs to be done to understand the complexities of the support industry provided to the NNI.

[82] Quote from p. 272 of Roco and Bainbridge, Societal Implications. Mikulski's support of science, and NASA in particular, is detailed in Munson, The Cardinals of Capitol Hill, which provides an insightful look at the appropriations process.

[83] Roco and Bainbridge, Societal Implications, 272.

[84] National Science and Technology Council, 'National Nanotechnology Initiative.' This was submitted by the Subcommittee on Nanoscale Science. Engineering, and Technology (NSET), chaired by Roco, which replaced the earlier IWGN. 
[85] National Science and Technology Council, 'National Nanotechnology Initiative,' 42.

[86] The 'Grand Challenges' areas were to receive a total of some US\$133 million, \$62 million more than the previous year. Some of this was to administered by the NSF but the Department of Defense was slated to be the single largest recipient of 'Grand Challenge' funds.

[87] Some US $\$ 28$ million (about $6 \%$ of the NNI funding) was set also aside for workforce training and studying societal and ethical implications. National Science and Technology Council, 'National Nanotechnology Initiative,' 30.

[88] Of this, the NSF received US\$150 million; the Department of Defense US\$125 million.

[89] Markoff, 'California Sets Up 3 Centers.'

[90] The effects of the terrorist attacks of 11 September 2001 on funding for nanotechnology is complex and cannot be more than noted here. An 3 August 2003 letter from John H. Marburger, Pres. Bush's science advisor noted that nanotechnology was 'essential to achieving the President's top three priorities: winning the war on terrorism, securing the homeland, and strengthening the economy;' included in National Science and Technology Council, 'National Nanotechnology Initiative: Research and Development' (Supplement to the President's FY 2004 Budget).

[91] US\$982 million was requested for fiscal year 2005 alone.

[92] Sarewitz, 'Does Science Policy Exist,' notes the relation, for better or worse, between budgets and policy in the USA.

[93] Fewer than $30 \%$ of people polled had heard of 'nanotechnology' and less than $20 \%$ could offer a reasonable definition of it. The Royal Society, Nanoscience and Nanotechnologies,' 11.

[94] Johnson, 'The End of Pure Science?' while the term post-academic science' is itself from Ziman, Real Science.

[95] Ziman, Real Science, 73.

[96] The literature on this phenomenon is vast; a classic paper on the topic is Etzkowitz, 'Entrepreneurial Science in the Academy.'

[97] For example, for fiscal year 2003 the Bush Administration added another 'Grand Challenge' to the NNI which would focus on homeland security via detection and protection against chemical, biological, explosive, and radiological (CBER) threats.

[98] Editors, 'Megabucks for Nanotech.'

[99] Baird and Shew, 'Probing the History,' 10.

[100] The focus on applications is clear in Congressional debates over science budgets. As Jones, 'House Appropriations Bill' notes, discussion of the fiscal 2005 budget referring to nanotechnology specifically asks the NSF to increase research support for practical applications such as improving semiconductor devices.

[101] Roco, 'The US National,' 3.

[102] Riordan, 'The Demise.'

[103] Heilbron and Kevles offer a comparison between the SSC and the Human Genome Project in 'Finding a Policy; also Cook-Deegan, 'The Human Genome Project.'

[104] Nowotny and Felt, After the Breakthrough.

[105] Roco et al., Nanotechnology Research Directions, x.

[106] Evelyn $\mathrm{Hu}, 4$ January 2005 personal communication with the author.

[107] Roco, 'The US National,' 6.

[108] For example, an article by Drexler's wife and partner at the Foresight Institute draws a direct line from the Greek concept of the atom to the future benefits of nanotechnology, suggesting the inevitability of this path; Peterson, 'Nanotechnology.'

[109] Nye, 'Technological Prediction,' 171.

[110] Roco, 'Coherence and Divergence;' Roco and Bainbridge, 'Converging Technologies.'

[111] Quotes from Roco and Bainbridge, 'Converging Technologies,' 285 and 289.

[112] Roco and Bainbridge, 'Converging Technologies;' 281. 
[113] According to Evelyn Hu, Roco's emphasis on nano's convergence with others areas of research may be part of a 'deliberate repackaging' of the NNI to ensure that interest and funding remain strong. Evelyn $\mathrm{Hu}, 4$ January 2005 personal communication with the author.

[114] Del Sesto, 'Wasn't the Future,' 61.

[115] McCurdy, Space and the American Imagination.

[116] Committee for the Review of the National Nanotechnology Initiative, Small Wonders, Endless Frontiers.

[117] The 2003 publication of Michael Crichton's bestselling potboiler Prey, the plot of which centers around hostile swarms of nanomachines, undoubtedly tarnished the limited public perception of nanotechnology as well.

[118] Monastersky, 'The Dark Side of Small;' Swiss-Re, 'Nanotechnology.'

[119] House of Representatives Committee on Science, 'Societal Implications of Nanotechnology,' 49.

[120] Drexler, 'Nanotechnology.'

[121] Seagal, Technological Utopianism.

\section{References}

Amato, Ivan. 'The Apostle of Nanotechnology.' Science 254, no. 6036 (1991): 1310-11.

- Nanotechnology: Shaping the World Atom by Atom. Washington, DC: National Science and Technology Council, 1999.

Atkinson, William I. Nanocosm: Nanotechnology and the Big Changes Coming from the Inconceivably Small. New York City: Amacom, 2003.

Baird, Davis, et al., eds. Discovering the Nanoscale: A Reader of Workshop Manuscripts; from an International Conference at Darmstadt Technical University, October 9-12, 2003. Darmstadt: Darmstadt Technical University, 2003.

— - and Ashley Shew. 'Probing the History of Scanning TunnelingMicroscopy.' In Discovering the Nanoscale: A Reader of Workshop Manuscripts; from an International Conference at Darmstadt Technical University, October 9-12, 2003, edited by Davis Baird et al. Darmstadt: Darmstadt Technical University, 2003: 3-19.

Barber, D. J., and I. C. Freestone. 'An Investigation of the Origin of the Color of the Lycurgus Cup by Analytical Transmission Electron Microscopy.' Archaeometry 32, no. 1 (1990): 33-45.

Boesman, William C. (coordinator). 'Analysis of Ten Selected Science and Technology Policy Studies.' Washington, DC: Congressional Research Service, 1997.

Brown, J. S. 'Don't Count Society Out: A Response to Bill Joy.' In Societal Implications of Nanoscience and Nanotechnology, edited by Mihail C. Roco and William Sims Bainbridge. Boston: Kluwer Academic Publishers, 2001.

Committee for the Review of the National Nanotechnology Initiative. Small Wonders, Endless Frontiers: A Review of the National Nanotechnology Initiative. Washington, D.C.: Committee for the Review of the National Nanotechnology Initiative, Division on Engineering and Physical Sciences, National Research Council, 2003.

Cook-Deegan, Robert Mullan. 'The Human Genome Project: The Formation of Federal Policies in the United States, 1986-1990.' In Biomedical Politics, edited by Kathi Hanna. Washington, DC: National Academy Press, 1991: 99-167.

Corn, Joseph, ed. Imagining Tomorrow: History, Technology, and the American Future. Cambridge, MA: MIT Press, 1986.

—. 'Epilogue,' In Imagining Tomorrow: History, Technology, and the American Future, edited by Joseph J. Corn. Cambridge, MA: The MIT Press, 1986: 219-29.

Crawford, Robert. 'Japan Starts a Big Push Toward the Small Scale.' Science 254, no. 5036 (1991): 1304-05.

Crow, Michael M. and Daniel Sarewitz. 'Nanotechnology and Societal Transformation.' In AAAS Science and Technology Policy Yearbook, edited by Albert H. Teich et al. Washington, DC: AAAS, 2001: 89-101. 
Council on Competitiveness called 'Science in the National Interest.' Washington, DC: National Science and Technology Council, 1994.

Davey, Michael E. 'Manipulating Molecules: The National Nanotechnology Initiative.' CRS Report no. RS20589, 2000.

Del Sesto, Steven L. 'Wasn't the Future of Nuclear Engineering Wonderful?' In Imagining Tomorrow: History, Technology, and the American Future, edited by Joseph J. Corn. Cambridge, MA: The MIT Press, 1986: 58-76.

Drexler, K. Eric. 'Molecular Engineering: An Approach to the Development of General Capabilities for Molecular Manipulation.' Proceedings of the National Academy of Science 78, no. 9 (1981): 5275-78.

- Engines of Creation: The Coming Era of Nanotechnology. New York: Anchor Books, 1986.

. 'Nanotechnology: From Feynman to Funding.' Bulletin of Science, Technology, and Society 24, no. 1 (2004): 21-27.

Du Charme, Wesley M. Becoming Immortal: Nanotechnology, You, and the Demise of Death. Evergreen, CO: Blue Creek Ventures, 1995.

Eigler, D. M. and E. K. Schweizer. 'Positioning Single Atoms with a Scanning Tunneling Microscope.' Nature 344, no. 6266 (1990): 524-26.

Editors. 'Megabucks for Nanotech.' Scientific American 285, no. 3 (2001): 8.

Etzkowitz, Henry. 'Entrepreneurial Science in the Academy: A Case of Transformation of Norms,' Social Problems 36, no. 1 (1989): 14-29.

Feynman, Richard P. 'There's Plenty of Room at the Bottom.' Engineering and Science 23, no. 5 (1960): 22-26.

Fogelberg, Hans and Hans Glimell. Bringing Visibility to the Invisible: Towards a Social Understanding of Nanotechnology. Goteborgs: Goteborgs Universitet, 2003; URL link is http://www.sts.gu.se/ publications/STS_report_6.pdf.

Gieryn, Thomas. Cultural Boundaries of Science: Credibility on the Line. Chicago, IL: The University of Chicago Press, 1999.

Gingrich, Newton L. 'February 12, 1997 letter to House Committee on Science Chairman F. James Sensenbrenner, Jr.:' http://www.house.gov/science/science_policy_study.htm.

Glimell, Hans. 'Grand Visions and Lilliput Politics: Staging the Exploration of the "Endless Frontier."' In Discovering the Nanoscale: A Reader of Workshop Manuscripts; from an International Conference at Darmstadt Technical University, October 9-12, 2003, edited by Davis Baird et al. Darmstadt: Darmstadt Technical University, 2003: 147-64.

Heilbron, John L. and Daniel Kevles. 'Finding a Policy for Mapping and Sequencing the Human Genome: Lessons from the History of Particle Physics.' Minerva 26, no. 3 (1988): 299-314.

House of Representatives Committee on Science. 'Unlocking our Future: Toward a New National Science Policy.' Washington, DC, US Government Printing Office, 1998: http:// www.house.gov/science/science_policy_report.htm.

—. 'Nanotechnology: The State of Nano-Science and its Prospects for the Next Decade.' Washington, DC, US Government Printing Office, 1999.

—. 'The Societal Implications of Nanotechnology: Hearing before the Committee on Science.' Washington, DC, US Government Printing Office, 2003.

Johnson, Ann. 'The End of Pure Science? Science Policy from Bayh-Dole to the National Nanotechnology Initiative.' In Discovering the Nanoscale: A Reader of Workshop Manuscripts; from an International Conference at Darmstadt Technical University, October 9-12, 2003, edited by Davis Baird et al. Darmstadt: Darmstadt Technical University, 2003: 20-33.

Jones, David E. H. 'Technical Boundless Optimism.' Nature 374, no. 6525 (1995): 835-37.

Jones, Richard M. 'Aboard Air Force One: Press Briefing by Neal Lane and Rita Colwell.' FYI: The AIP Bulletin of Science Policy News, no. 10 (2000); available at: http://www.aip.org/fyi/2000/ fyi00.010.htm.

—. 'Former House Speaker Gingrich on Doubling Research Funding.' FYI: The AIP Bulletin of Science Policy News, no. 154 (1999); available at: http://www.aip.org/fyi/1999/fyi99.154.htm. 
'House Appropriations Bill Recommends Cut in FY 2005 NSF Funding.' FYI: The AIP Bulletin of Science Policy News, no. 99 (2004); available at: http://www.aip.org/fyi/2004/099.html.

Joy, William N. 'Why the Future Doesn't Need Us.' Wired 8, no. 4 (2000): 238-62.

Kingdon, John W. Agendas, Alternatives, and Public Policies. New York: Addison-Wesley-Longman, 1995.

Korsmo, Fae L. and Michael P. Sfraga. 'From Interwar to Cold War: Selling Field Science in the United States, 1920s through 1950s.' Earth Sciences History 22, no. 1 (2003): 55-78.

Leath, Audrey. 'Senate Science and Technology Caucus Holds Briefing on Nanotechnology.' FYI: The AIP Bulletin of Science Policy News, no. 44 (2000); available at: http://www.aip.org/fyi/ 2000/fyi00.044.htm.

—. 'Administration and Congress See Promise in Nanotechnology.' FYI: The AIP Bulletin of Science Policy News, no. 46 (2000); available at: http://www.aip.org/fyi/2000/fyi00.046.htm.

— _ 'NSF Hearing: Good News, Bad News.' FYI: The AIP Bulletin of Science Policy News, no. 51 (2000); available at: http://www.aip.org/fyi/2000/fyi00.051.htm.

Markoff, John. 'California Sets Up 3 Centers for Basic Scientific Research.' The New York Times, 20 December 2000: A30.

McCurdy, Howard E. Space and the American Imagination. Washington, DC: Smithsonian Institution Press, 1997.

Meyer, Martin. 'Patent Citation Analysis in a Novel Field of Technology: An Exploration of NanoScience and Nano-Technology.' Scientometrics 51, no. 1 (2001): 163-83.

Milburn, Colin. 'Nanotechnology in an Age of Posthuman Engineering: Science Fiction as Science.' Configurations 10, no. 2 (2002): 261-95.

Mody, Cyrus. 'From the Topografiner to the STM and the AFM: What the History of Probe Microscopy Might Tell Us About Nanoscience.' In Discovering the Nanoscale: A Reader of Workshop Manuscripts; from an International Conference at Darmstadt Technical University, October 9-12, 2003, edited by Davis Baird et al. Darmstadt: Darmstadt Technical University, 2003: 59-77.

Monmaney, Terrance. 'Nanomachines to Our Rescue.' The New York Times 10 August 1986: BR 8.

Munson, Richard. The Cardinals of Capitol Hill: The Men and Women who Control Government Spending. New York: Grove Press, 1993.

Monastersky, Richard. 'The Dark Side of Small: As Nanotechnology Takes Off, Researchers Scramble to Assess its Risks.' The Chronicle of Higher Education, 10 September 2004, A12.

National Science and Technology Council. 'National Nanotechnology Initiative: The Initiative and Its Implementation Plan.' Washington, D.C., Subcommittee on Nanoscale Science, Engineering and Technology, 2000.

- 'National Nanotechnology Initiative: Research and Development Supporting the Next Industrial Revolution, Supplement to the President's FY 2004 Budget.' Washington, D.C., Subcommittee on Nanoscale Science, Engineering, and Technology, 2003.

Nowotny, Helga and Ulrike Felt. After the Breakthrough: The Emergence of High Temperature Superconductivity as a Research Field. Cambridge: Cambridge University Press, 1997.

Nye, David E. 'Technological Prediction: A Promethean Problem.' In Technological Visions: The Hopes and Fears that Shape New Technologies, edited by Marita Sturken, Douglas Thomas and Sandra Ball-Rokeach. Philadelphia: Temple University Press, 2004: 159-76.

Office of the Press Secretary. 'White House Releases National Science Policy Report.' Washington, DC, The White House, August 3, 1994.

Office of Science and Technology Policy. 'National Nanotechnology Initiative: Research and Development Funding in the President's 2005 Budget.' Washington, DC: Office of Science and Technology Policy, 2004: http://www.ostp.gov/html/budget/2005/FY05NNI1-pager.pdf.

Peterson, Christine L. 'Nanotechnology: Evolution of the Concept.' In Prospects in Nanotechnology: Toward Molecular Manufacturing, edited by Markus Krummenacker and James Lewis. New York: Wiley, 1995: 173-86.

Regis, Edward. Nano! Remaking the World Atom by Atom. Boston: Little, Brown, 1995. 
Riordan, Michael. 'The Demise of the Superconducting Super Collider.' Physics in Perspective 2, no. 4 (2000): 411-25.

Roco, M. C. 'Towards a US National Nanotechnology Initiative.' Journal of Nanoparticle Research 1, nos. 5-6 (2000): 435-38.

—. 'International Strategy for Nanotechnology Research and Development.' Journal of Nanoparticle Research 3, nos. 5-6 (2001): 353-60.

—. 'Coherence and Divergence of Megatrends in Science and Engineering.' Journal of Nanoparticle Research 4 (2002): 9-19

- ' 'Broader Societal Issues of Nanotechnology.' Journal of Nanoparticle Research 5, nos. 3-4 (2003): 181-89.

—. 'The US National Nanotechnology Initiative after 3 years (2001-2003),' Journal of Nanoparticle Research 6 (2004): 1-10.

—, S. Williams, and P. Alivisatos, eds. Nanotechnology Research Directions: IWGN Workshop Report. Baltimore, MD: World Technology Evaluation Center, 1999.

—, and William S. Bainbridge, eds. Societal Implications of Nanoscience and Nanotechnology. Boston: Kluwer Academic Publishers, 2001.

—, and W. S. Bainbridge. 'Converging Technologies for Improving Human Performance: Integrating from the Nanoscale.' Journal of Nanoparticle Research 4 (2002): 281-295.

Sabatier, Paul A., ed. Theories of the Policy Process. Boulder, CO: Westview Press, 1999.

Sarewitz, Daniel. 'Does Science Policy Exist, and If So, Does it Matter: Some Observations on the U.S. R\&D Budget.' Discussion Paper for Earth Science Institute; Science, Technology, and Global Development Seminar, 2003.

Science Committee on Commerce, Science, and Transportation (Subcommittee on Science, Technology, and Space), United States Senate. 'New Technologies for a Sustainable World.' Washington, DC: Subcommittee on Science, Technology, and Space of the Committee on Commerce, Science, and Transportation, United States Senate, 102nd Congress, Second Session, 1992.

Seagal, Howard P. Technological Utopianism in American Culture. Chicago, IL: The University of Chicago Press, 1985.

Siebert, Charles. 'The Next Frontier: Invisible.' The New York Times Magazine, 29 September 1996: 137-139.

Siegel, Richard W., Evelyn Hu, and M. C. Roco, eds. WTEC Workshop Report on R\&D Status and Trends in Nanoparticles, Nanostructured Materials, and Nanodevices in the United States. Baltimore, MD: International Technology Research Institute, 1998.

—. 'Nanostructure Science and Technology: A Worldwide Study.' Baltimore, MD, World Technology Evaluation Center, 1999.

Southwick, Ron. 'Nanotechnology, the Study of Minute Matter, Becomes a Big Priority in the Budget.' The Chronicle of Higher Education 2000: A38.

Stix, Gary. 'Waiting for Breakthroughs.' Scientific American 274, no. 4 (1996): 94-99.

Sturken, Marita, Douglas Thomas, and Sandra J. Ball-Rokeach, eds. Technological Visions: The Hopes and Fears that Shape New Technologies. Philadelphia, PA: Temple University Press, 2004.

Swiss-Re. 'Nanotechnology: Small Matter, Many Unknowns.' Swiss Reinsurance Company, 2004.

Taniguchi, Norio. 'On the Basic Concept of "Nano-Technology."' In Proceedings of the International Conference of Production Engineering. Vol. 2. Tokyo: Japan Society of Precision Engineering, 1974.

The Royal Society. Nanoscience and Nanotechnologies: Opportunities and Uncertainties. London: The Royal Society, 2004.

The White House: Office of the Press Secretary. 'National Nanotechnology Initiative: Leading to the Next Industrial Revolution.' 21 January 2000; this document is available at: www.whitehouse.gov/news/releases/2003/12/20031203-7.html.

Ziman, John. Real Science: What it Is and What it Means. New York: Cambridge University Press, 2000. 